\title{
IHI-VOITH 最新抄紙機の展開
}

\author{
ハインドル社 E．クラウスアウフ \\ フォイオト社 F。ジッペル \\ 石川島播穈重工業株式会社 竹 内 正 迪
}

\section{The newsprint machine start-up at Haindl, Schongau mill}

\author{
Dr. E. Krauthauf \\ Haindl Paper GmbH \\ Dr. F. Zippel \\ J. M. Voith GmbH
}

In autum 1989, a new machine was start-up at Haindle paper Schongau mill, Germany. Initial, the supplier reports on the conception of paper machine and winder. Subsequently, the operator gives a survey of the commissioning period and technological results.

\section{Analysis of runnability problem in the paper machine and mordern concepts of paper drying}

\author{
M. Takeuchi \\ Ishikawajima-Harima Heavy industries Co., Ltd.
}

The first part of paper deals with the phenamena that influence the runnability of web in the paper machine. The second part describes the new designs of a dryer section.

\section{The future press setion for newsprint}

\author{
M. Takeuchi \\ Ishikawajima-Harima Heavy industries Co., Ltd.
}

For the future newsprint machine is can be expected that by the application of the shoe press system (FNP : Flexonip press) the number of press nips will be reduced. Compared to the roll, presses used today much higher dryness could be achieved.

はじめに

近年, 抄紙技術の発達はすばらしく，高速化に関す る諸問題は関係各機関の努力により解決されてきてお ク，結果的に製紙業界全体の省資源，省エネルギーに 貢献してきている。これに伴い設備の生産性を向上さ せるためには，より一層抄紙機の高速性能を安定させ ることが将来的に重要な課題となってきた。

以下に抄紙機の高速化に対するIHI-VOITHグ ループの取組みの一端を“最新新聞抄紙機のスタート
アップ”＂ドライエンドにおける最近の技術開発”お よび“フレキソニッププレスの展望とその応用”とし て紹介する。

\section{1. 最近新聞抄紙機のスタートアップ}

1989 年の秋, 最近の新聞マシンが Haindl 製紙, Schongau 工場で稼動した(図 1 a)。Haindl 社はドイ ツで第 3 位の生産を誇る製紙会社であり，その Shongau工場はドイッ南部の都市 Shongauにあり新聞用 

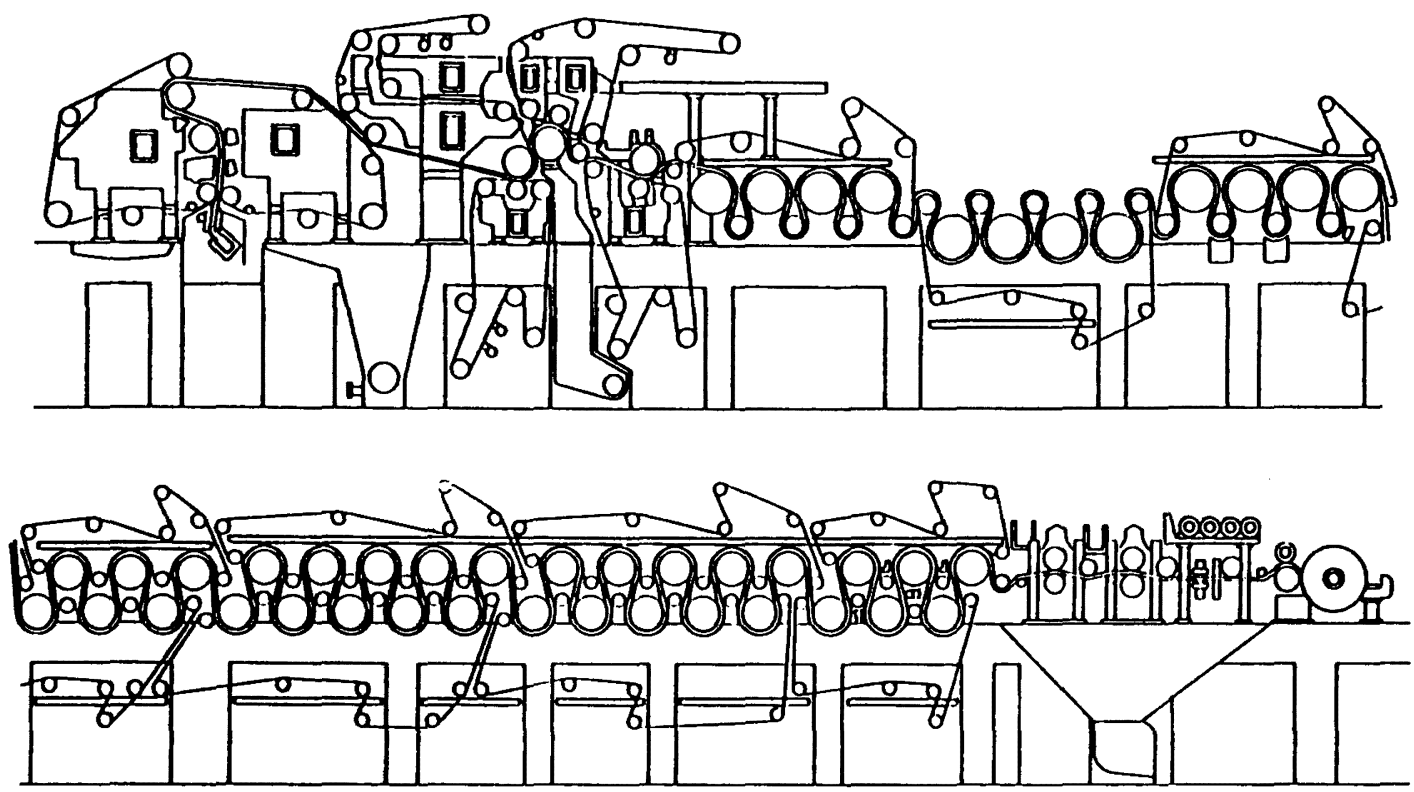

図 1 a PM 7 全体図

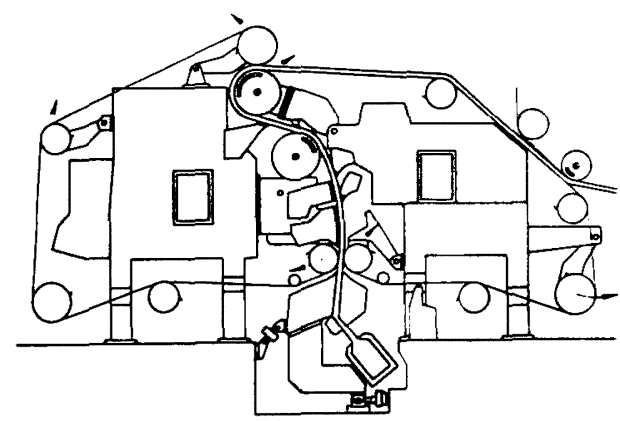

図 1 b デュオフォーマCV

紙を生産している。この新マシン (PM 7) はVOITH 社 (ドイッ) との契粎からわずか 19 ケ後にスタート アップした。PM 7 の来年の生産量は $45 \sim 54 \mathrm{~g} / \mathrm{m}^{2}$ を 基準として，230,000 $\mathrm{t}$ に達する見込みである。最初 にマシンサプライヤーであるVOITH 社が抄紙機と ワインターについて構成と特徵を紹介し，引き続いて 操業者 (Schongau 工場) の立場から試運枟期間中の 技術調查結果を報告する。

\section{1 設借の概要}

生産品目：新閏用紙 $\left(40 \sim 54 \mathrm{~g} / \mathrm{m}^{2}\right)$

ワイヤー幅: $9,150 \mathrm{~mm}$

トリム幅: $8,500 \mathrm{~mm}$

抄速: $1,400 \mathrm{~m} / \mathrm{min}(\mathrm{Max})$.

設計抄速 : $1,700 \mathrm{~m} / \mathrm{min}$
生産量: $840 \mathrm{~T} / \mathrm{D}$

新マシンのコンセプトは以下の要望点を調和させる ことが必要であった。

・抄紙機の高速化と製品品質の向上

・Schongau 工場に納入した高速新聞マシンでの経 験を生かす。特に抄紙機構成上，効果が上がった 主要な装置についての経験を生かす。

1.2 フォーミングセクション

ワイヤーセクションでは, バーチカルギャップ フォーマタイプCV（図1b) を採用した。これはブ レート/ロールフォーマであり，このフォーマーの初 期地合は独特なカーブを持つドレネージシューやデフ レクターなどの固定エレメントでパルス脱水をして形 成される。

次に, シートはフォーミンクロールで両面脱水され サクションクーチロールに入る。ヘッドボックスは旋 回形のハイタピュレンスヘッドホッックスで, スライス 開度のコントロールができるプロフィルマチックシス テムを装置している。両ワイヤ一共, ブレストロール 入口側にワイヤースプレッターロールを配置している。

\section{3 プレスセクション}

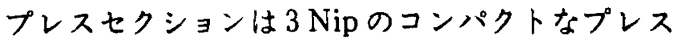
(Duo-セントリII型) と，トップにスムーズロールを

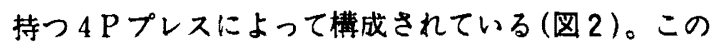
プレスは高速操業においてもスムーズな操業が出来る 


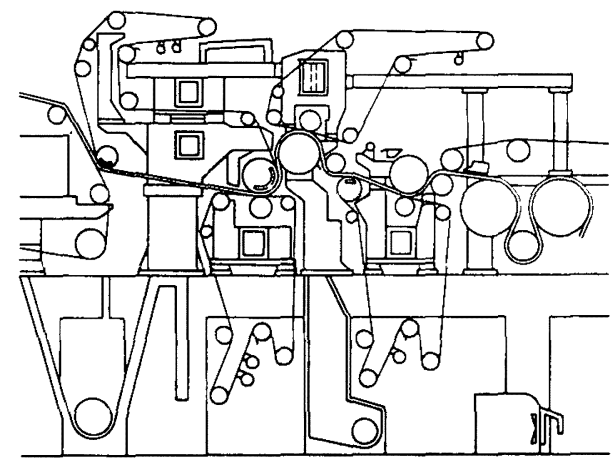

図2 プレスセクション

よう安定性のある強固なフレーミンクや, フリーラン を出来るだけ少なくしたシートパスを特徴とする。ま た４Ｐ放ドライヤへはトランスファフォイル を使用することにより，より安定した通紙が可能と なった。林面は両面共 2 回フェルトに接し、さらに 1 回はスムーズロールに接する。そのためデュオフォー マで得られる両面性がらに改善される。センター

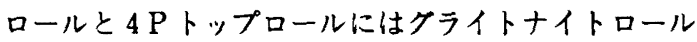
に代って，特殊カパー巻のプレスロールを採用した。 1 P， $3 \mathrm{P}, 4 \mathrm{P}$ には溝付き NIPCO スチールロールを選 択し，2Pサクションプレスロールはポリエチレンカ パー巻きである。

\section{4 ドライヤーセクション}

ドライヤーセクションは高速運枟スピードと要求さ れる上級品犋紙に対する新しい考えをもつものである (図 3)。

最初の 3 群はシートテンションフリーの乾燥ができ るシンクルティヤーを採用した。この 3 群のドライ ヤーには 12 本の $2,200 \mathrm{~mm}$ 徍ドライヤーとその間に $1,000 \mathrm{~mm}$ 徍のサクションカンバスロールを交互に配 置している。このアレンジによって，シートの強度が まだ弱い段階でも紙切れを起こさず安定した操業性を 得ることかできる。

4 群以降のドライヤは $1,800 \mathrm{~mm}$ 径ドラム 32 本を
4 クループ ( 4 群〜 7 群) に別けてコンベンショナル なタブルテイャー形に配置している。

ここでは特徴ある装置である吸/引複合形のロール をキャンバスロールの位置に配置して，M/C 方向に エアー流れをさせすにドライヤーポケットのへンンチ レーションを行っている。最終の7群にはフフローボッ クスがあり，さらに効果的なエアーへンチレーション と水分プロファイルの調整を行う。

\section{5 ソフトカレンター}

新マシンは一般のカレンタースタックに代ってエッ シャーウイス社の Nipco-Mat, ソフトカレンタース タックを 2 基備えており，新しいコンセプトの1つと なっている。

\section{6 ドライブ・計装・品留管理}

最新アシンの適正なる操業を行うために必須となる ものはドライブと計装制御である。マシンには 26 台 のドライブがあり，そのドライブには $\mathrm{ABB}$ 社の周波 数制御システムでドライブされる ACモー夕を採用し た。VOITH 社はマシンの制御システムを採用し，プ ロセスオートコントロールシステムは Altim-Lipple 社が製作した。製品の品犋コントロールのため以下の 装置を装備している。

・ 3 群ドライヤー下部に水分プロファイルの修正の ため,ノズムモイスチャーライザー設置。

・カレンタスタックにはキャリパーコントロールア のためエアープローノズルを設置。

・リール前では Lipple B/M 計により坪量, 水分, キャリパーのコントロールを行う。

\section{7 ワインタ}

新マシンには新しいコンセプトを持ったワインタ, デュオローラIIを採用した(図4)。このワインタは最 新の印刷機のニースにあったもので広幅, 超大径の巻 取を行うことができるフルオートマチックのワインタ である。最大巻取重量は $6 \mathrm{t}$ まで可能であり, 巻取速 度は最高 $2,500 \mathrm{~m} / \mathrm{min}$, フルオートマチック化された コントロールシステムにより各々の巻取ロールの自重 をキャンセルできるので巻取ロールも硬さが一定にで

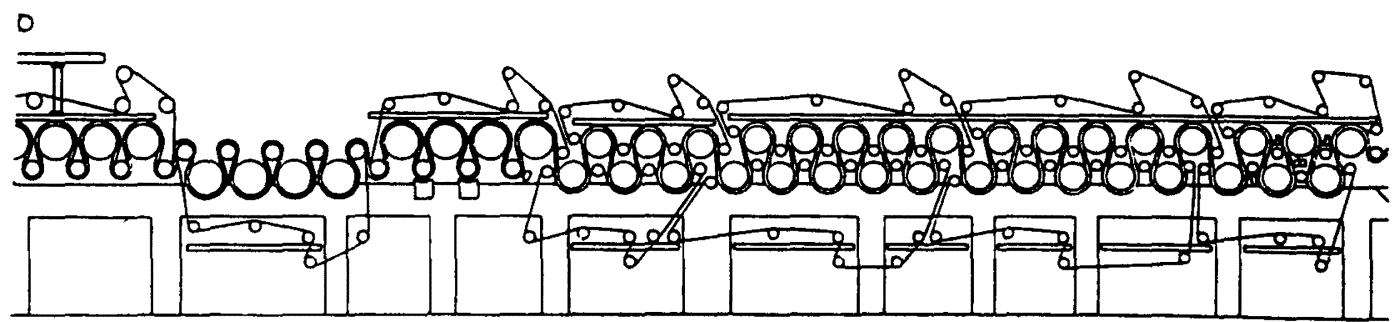

図 3 ドライヤセクション 


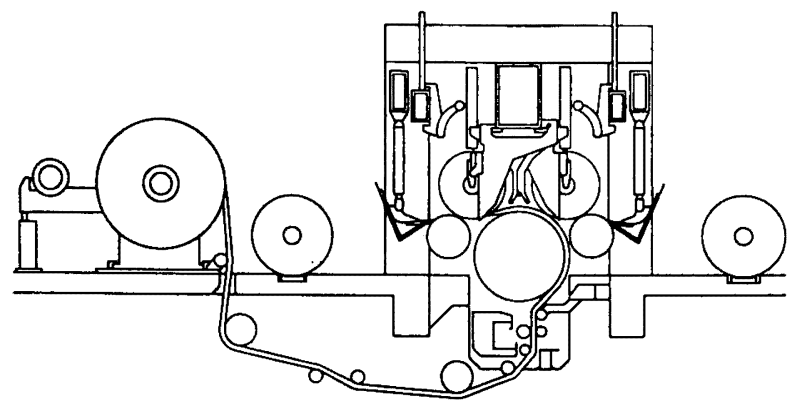

図 4 ワインタ・デュオローラII

表 1 平均的な原料配合

\begin{tabular}{l|l|r|r}
\hline & & PM 7 & Mill. \\
Deinked waste paper pulp & kg pulp(B.D.)/t paper & 600 & 580 \\
TMP & kg pulp(B.D.)/t paper & 200 & 200 \\
Thermo groundwood pulp & kg pulp(B.D.)/t paper & 100 & 120 \\
Filler (Clay) & kg/t paper & 25 & 25 \\
Monthly averages & & & \\
\hline
\end{tabular}

きる。さらに最新のコンピューターコントロールによ り全自動化されており，特にスリッターのオートセッ ト，自動枠替えなどにより端に枠替え時間が短く なった。

\section{8 パルブ原料}

Schongau 工場では脱量古轱パルプ(DIP)，TMPお よびGP を生産している。古柾処理プラントは 1,200 $\mathrm{t} /$ 日の仕込み能力を有し, 約 $950 \mathrm{t} /$ 日の仕上り DIPを 生産している。原料配合は家庭回収古紙 85\%，新開古 林 $8 \%$ と雑誌古耙 $7 \%$ である。脱墨プロセスは VOITH フローテーションシステムを採用している。 仕上りのDIP は $30 \%$ 浱度に浱樎され,ティィハージョ ンシステムに送られる。表 1 にPM 7 と工場全体に関 する平均的な原料配合を示す (但し, $47 \sim 48 \mathrm{~g} / \mathrm{m}^{2}$ ) の 平均坪量を基準としたデーターである)。PM 7 では工 場平均に比へて，やや DIP が多く使用されていること が分かる。

\subsection{PM 7 のスタートアップ}

PM 7 は 1989 年 11 月 15 日に抄速 $1,050 \mathrm{~m} / \mathrm{min}$ で スタートアップし，最初の紙を生産した。図 5 に過去 8ヶ月の抄速と生産量の推移を示す。下段のクラフに 示すようにPM 7 の生産量は安定して增加した。1990 年 7 月時点（スタートアップ後，8.5 ケ月）では 48.8 $\mathrm{g} / \mathrm{m}^{2}$ の新閒用紙を日産平均 $600 \mathrm{t}$ 以上生産した。上段 のクラフにリール上のマシンスピードの推移を示すが, 達成されたマシンスピードはいずれも目樘值を大幅に

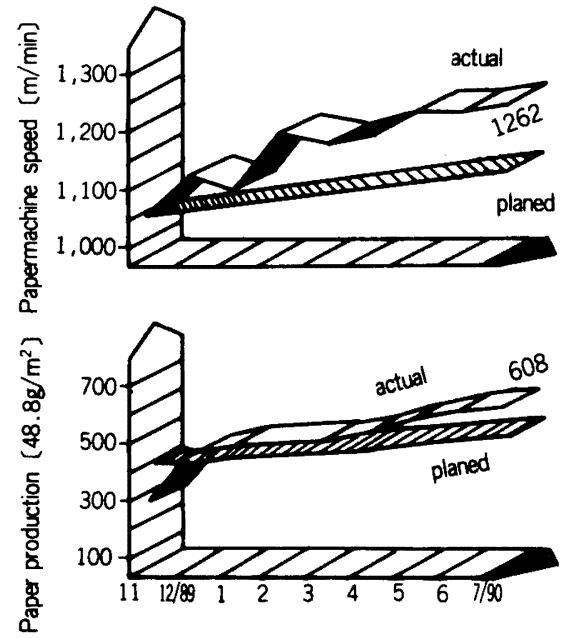

図 5 抄速と生産量の推移

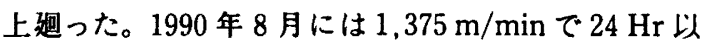
上運転され，その期間の最高抄速は $1,420 \mathrm{~m} / \mathrm{min} て ゙$ あった。

1.10 プロセスデータ

(1) ワイヤパート

表 2 に 3 台の高速マシンに関する白水データー （月間平均値）を示す。

- PM 6 : Duoformer CF (キャップフォーマー)

- PM 7 : Duoformer CV (キャップフォーマー)

- PM 9 : Duoformer H (ハイブリーズフォーマー) 
表 2 ストック・白水データ

\begin{tabular}{l|c|c|c}
\hline Papermachine No. & 6 & 7 & 9 \\
Supplier & Voith & Voith & Voith \\
Duoformer type & $\mathrm{CF}$ & $\mathrm{CV}$ & $\mathrm{H}$ \\
Papermachine speed & $1,253 \mathrm{~m} / \mathrm{min}$ & $1,262 \mathrm{~m} / \mathrm{min}$ & $1,100 \mathrm{~m} / \mathrm{min}$ \\
Consistencies & & & \\
Headbox & $11.0 \mathrm{~g} / l$ & $13.6 \mathrm{~g} / l$ & $13.3 \mathrm{~g} / l$ \\
White water & $6.0 \mathrm{~g} / l$ & $7.8 \mathrm{~g} / l$ & $8.1 \mathrm{~g} / l$ \\
Ash (Headbox) & $23 \%$ & $27 \%$ & $29 \%$ \\
First pass retention & & & \\
Total solids & $45.7 \%$ & $42.6 \%$ & $39.1 \%$ \\
Filler & $20.1 \%$ & $22.1 \%$ & $15.4 \%$ \\
Headbox temperature & $48^{\circ} \mathrm{C}$ & $46^{\circ} \mathrm{C}$ & $47^{\circ} \mathrm{C}$ \\
pH & 6.9 & 6.9 & 7.0 \\
Retention aid (kg/t paper) & 12 & 12 & 10 \\
Monthly average July 1990 & & & \\
\hline
\end{tabular}

表 3 ニップ压とドライネス

\begin{tabular}{l|c|c}
\hline & $\begin{array}{c}\text { Nip load } \\
{[\mathrm{kN} / \mathrm{m}]}\end{array}$ & $\begin{array}{c}\text { Dryness } \\
{[\%]}\end{array}$ \\
Duoformer CV & - & 16 \\
First press & 80 & n.a. \\
Second press & 85 & n.a. \\
Third press & 130 & $44.0 \pm 1.3$ \\
Fourth press & 150 & $47.0 \pm 0.6$ \\
Without steambox & & \\
Dryness at 12\% filler in paper & & \\
\hline
\end{tabular}

このデータよりこの 3 台の抄速は非常に高速である ことが分かる。また,ファーストパスリテンションは ハイフリッドフォーマーが一番低く，40\%を割った值 である。このように全体的に低い值となっている主な 要因, ヘッドホックスでの灰分含存率が $23 \sim 29 \%$ と高 いことに起因して、フィラーリテンションが約 $20 \%$ と 低くなっているためである。

(2) プレスパート

表 3 にプレスニップ圧と各点でのシートドライネス を示す。各ニップ圧はそれぞれ80,85, $130,150 \mathrm{KN} /$ $\mathrm{m}$ である。シートドライネスはフォーマー出口部 (ピックアップフェルトが湿紙をピックアップする直 前)で約 16\%であり, $3 \mathrm{P}$ 出口および $4 \mathrm{P}$ 出口でのシー トドライネスは，スチームボックスを使用しないでそ れぞれ平均值で $44.0 \pm 1.3 \%$ よび $47.0 \pm 0.6 \%$ あ る。

(3) ソフトカレンター

Schongau 工場では高速新网マシン（PM 9）に他社
に先立ってオンラインソフトカレンターを採用して， 紙品質とマシンの通伝性を優れたものにした。

衰 4 はPM 7 のソフトカレンタの運転年件を示して いる。

ソフトカレンターは特に多品種の紙を抄造するマシ ンやクレード替の多いマシンに関して洒値のある装呈 である。

\subsection{1 紙の品面}

PM 7 で生産される製品の品所は，他の 2 台の既設 マシンでは得られなかった水隼に達した。優れた地合, ソフトカレンタリンク, さらに非常に安定した MD/ $\mathrm{CD}$ 方向のプロファイルにより高品梊の製品が保証さ れた。

图 6 にハイフリッドフォーマーとギャップフォー マーから得られる地合評価（NUI Index）の比較を示 す。

困中の左側に 3 台のハイブリッドフォーマーについ てのテーターを示す。それらの NUI 值はほほ同等で 
表 4 ソフトカレンタの運転条件

\begin{tabular}{|c|c|c|}
\hline Rolltype & $\begin{array}{c}\text { Thermoroll Nipcotherm } \\
\text { Nipco F }\end{array}$ & $\begin{array}{c}\text { Softroll NipcoMat } \\
\text { Nipco F }\end{array}$ \\
\hline Rolldiameter & $1,120 \mathrm{~mm}$ & $1,025 \mathrm{~mm}$ \\
\hline Material & Chilled iron & Cast iron (GG 25) \\
\hline Softcover & & $\begin{array}{l}\text { Synthetic Polymer } \\
\text { (Febogloss M. } \\
\text { Softrock CC) }\end{array}$ \\
\hline Hardness & - & 91-93Shore D \\
\hline Operating Conditions & & \\
\hline Suriace temperature max. & $130^{\circ} \mathrm{C}$ & $70^{\circ} \mathrm{C}$ \\
\hline Nipload (line force) & $50-350 \mathrm{kN} / \mathrm{m}$ & \\
\hline
\end{tabular}

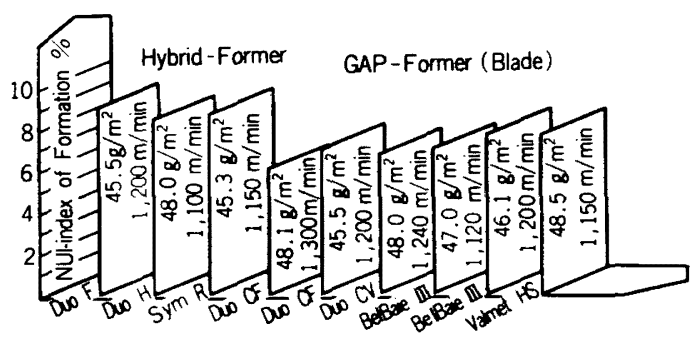

图 6 各フォーマの地合比較

あるが, 困中の右側に示す各社 4 台のキャップフォー マーに見られる NUI 値よりはかなり高いレべルあ る。

图 7 に灰分含有率 $11.5 \%$ のートの Z 方向におけ る兏分分布を示す。この分布パターンは, いずれのテ ストでも同し傾向を示し、シートのホトム側がトップ 僋より $2 \%$ 位多い灰分存有率となっている。

\subsection{2 桔}

Schongau 工場の新マシン（PM 7) は期待通りに稼 動し, 当初計画した生産量よりさらに高い生産量を達 成した。今回採用した新しいエレメントは,この試運 転中にそれらの有利性をすでに発揮している。我々の ユーザーから, PM 7 で生産する製品は以下の理由に
より十分に評価されている。

・均一な品質レベル, 均一な両面性, 優れた製品の 再現性等による高品皿性

・高速印刷機に於ける優れたシートの安定走行性

今後の目標としては,このマシンの総効率を $90 \%$ 以 上に保ち，かつ品質レベルも現状と同等に維持しなが ら $1,400 \mathrm{~m} / \mathrm{min}$ まで抄速アップを計ってゆくことで ある。

\section{2. ドライエンドにおける最新の技術開発}

抄秖機の走行安定性はウェットエンドに於いてはツ インワイヤフォーマ，4段プレスの発達などにより非 常に改善されてきている。これに伴いドライエンドの 問題がネックとなり初めてきた。

この問題の解決のための, 最初のステップはシンク ルカンバスの導入であった。そしてこのシンクルカン ハススの問題を解決し, 発展させたものがシンクルティ アドライヤである。この開発の背景を图8に示す。

本項では, このシンクルティアトライヤの開発過程 において明らかになった問題点を説明するとともに， その解決のための現実的な対応を説明したいと考える。

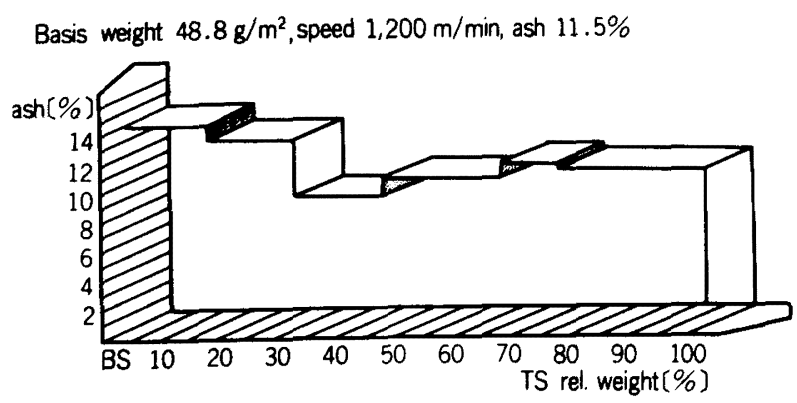

图 $7 Z$ 方向における兏分の分布 


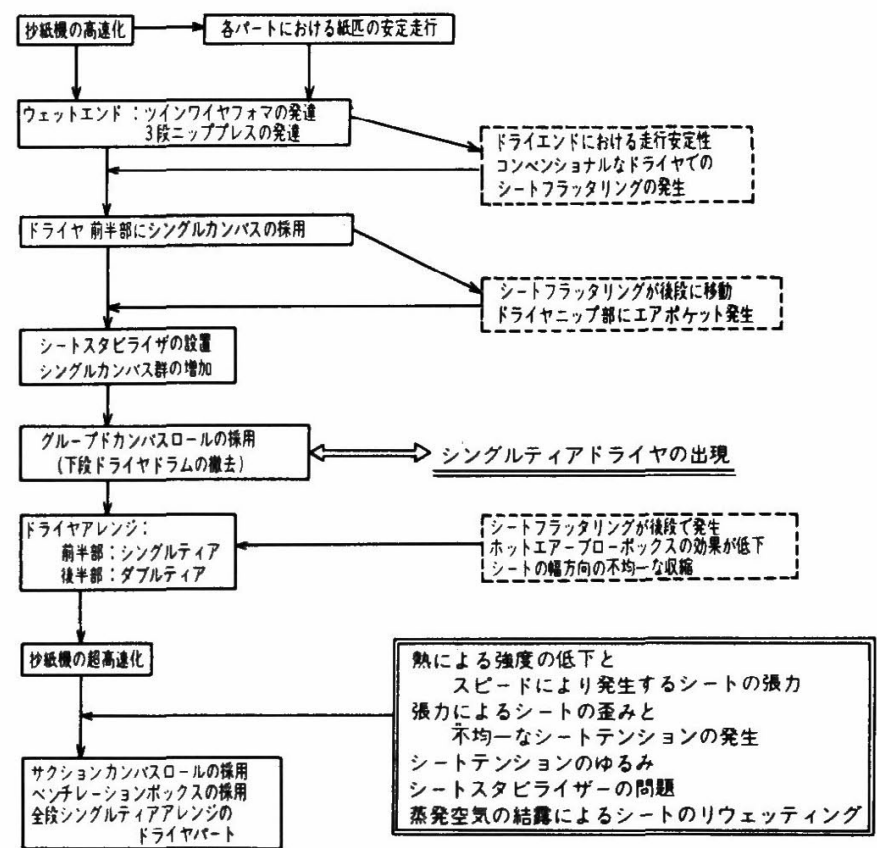

図 8 シングルティアドライヤ開発の背景

\section{1 熱によるシート強度の低下とスピードにより 発生するシートの張力}

熱によるシート強度の低下と，スピードによる保持 されていないシートの張力の発生は, より以上の增速 をする場合大きな障害となる。以下に述べることは, この事寒を説明している。图９は熱によるシートの強 度の低下を示すものであり, シートの温度 $38^{\circ} \mathrm{C}$ と $94^{\circ} \mathrm{C}$ における新聞用紙の裂断長とドライネスの関係を示し ている。横軸はドライネス，縦軸は裂断長である。例 えばドライネス $42 \%$ のと、温度の增加により製断長 が $90 \mathrm{~m}$ から約 $60 \mathrm{~m}$ に下がっている。これは水の粘度

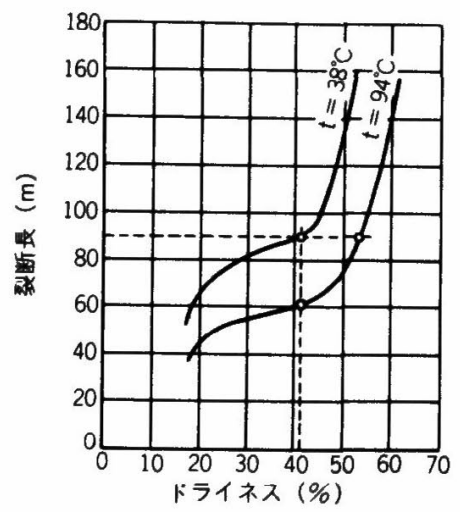

图 9 裂断長とドライネス
と表面張力の低下によって引き起こされるものと考え られる。また,この低下量は実に $33 \%$ と非常に大きい ものである。

曲率のまわりで, 保持されていないシートが走行す る場合に作用する遠心力はマシン方向の張力を作る。 图10はこの状態を表わし，さらにシートの張力 (T) と相当裂断長 (EBL) 公式の誘導を示している。この 公式から「保持されていないシートが直線からはずれ ている時はいつも張力が発生し, この張力はシートの 重量とスピードの 2 乗にのみ関係する」ということが 分かる。

图 11 はシートの温度とスピードによる張力によっ てスピードか制限されることを示しており，斜めの

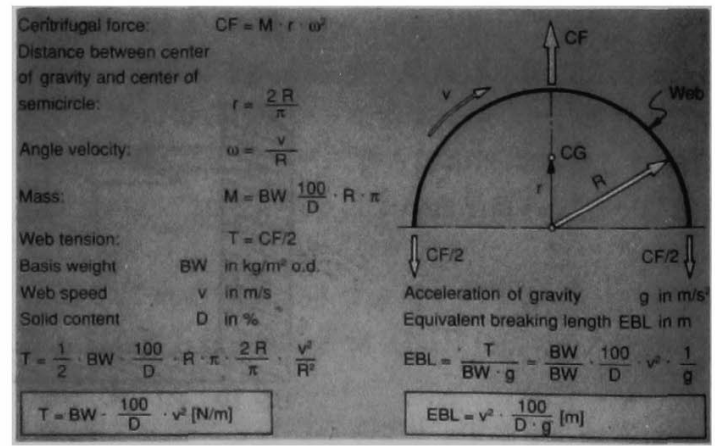

困10 スピードにより発生するシートの張力 


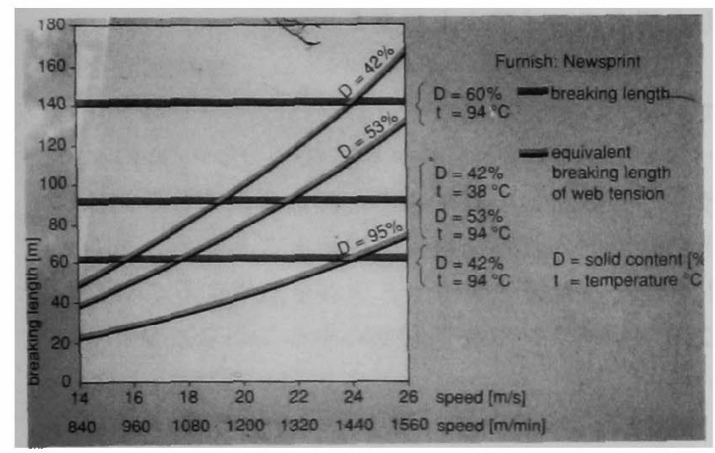

図 11 裂断長とスピード

カーブは 3 種類のドライネスに对する相当裂断長とス ピードの関係を, さらに，その 3 種類のドライネスに おいて温度が異なる場合の実際の裂断長を水平線で示 している。従ってカーブと水平線で囲まれた範囲が安 全限界を意味することになる。

例えばブレスパート後のドライネス $42 \%$ のシート ではドライヤ内で $950 \mathrm{~m} / \mathrm{min}$ のスピードで限界とな る。

図 11 はシートの安全走行にシートの温度とスピー トによる張力の影響が大きく作用するということを如 実に表わしている。

\section{2 引張りにより発生するシートの歪みとシート の張力}

図 12 はシートがプレスのハードロールからはがさ れる際に発生する引張力によって, シートかどのよう に変形するかを示している。

まず連繶したシートの有限な要素を考える。図 12 の上段はシートがハードロールからはがれる前にお けるそれぞれの要素の状態を表わしている。左の要素 は抄紙機中央部, 中央の要素は端部に近い部分, 右の 要素は右端部に位置するものとする。上述の引張力に よりそれぞれの要素は下段に示すように変形する。

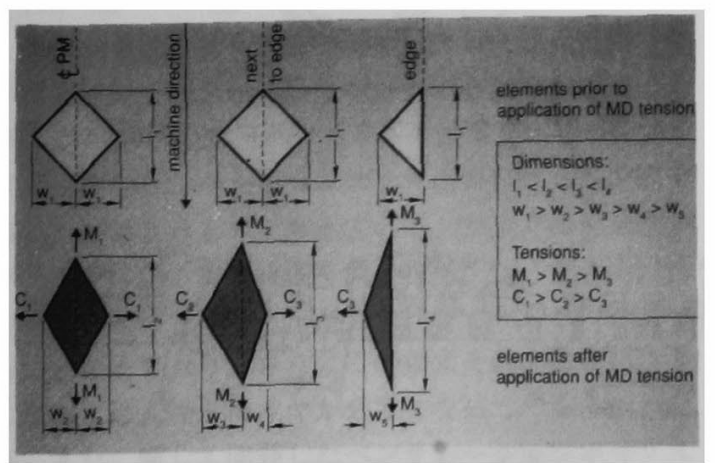

图 12 シートのひずみ

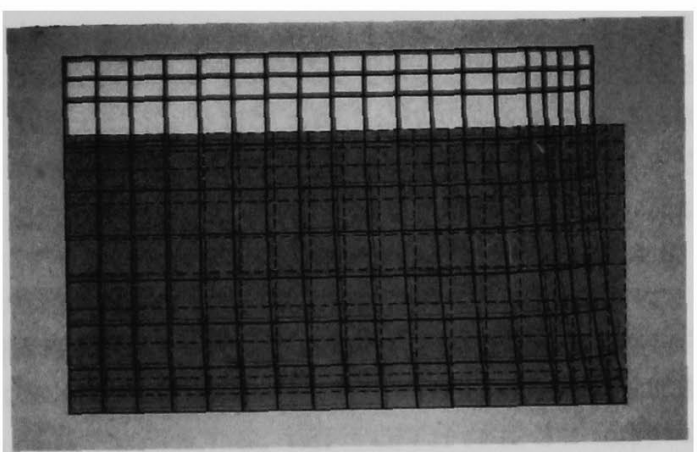

図 13 シートのひずみ

このように,シートの幅は决くなり特に端部が大き く変形し両耳がだれるのがよく分かる。

図 13 は図 12 で説明したことをコンピューターによ り解析したシートの歪みのパターンを表わしたもので ある。

\section{3 引張られたシートのゆるみ}

図 14 は引張られたシートの張力を一定に保とうと しても，時間と共にゆるみが発生することを示してい る。更に図 15 でこの“ゆるみ”による問題を述べる。 図に見られるエアポケットはシートのゆるみによって

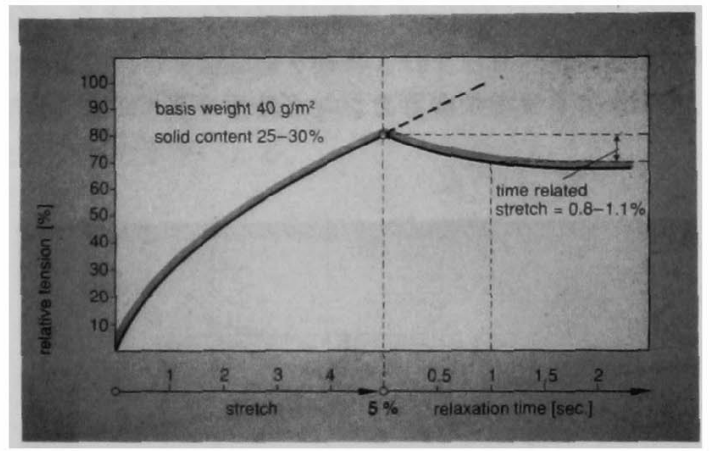

图 14 シートの張力とシートの伸び

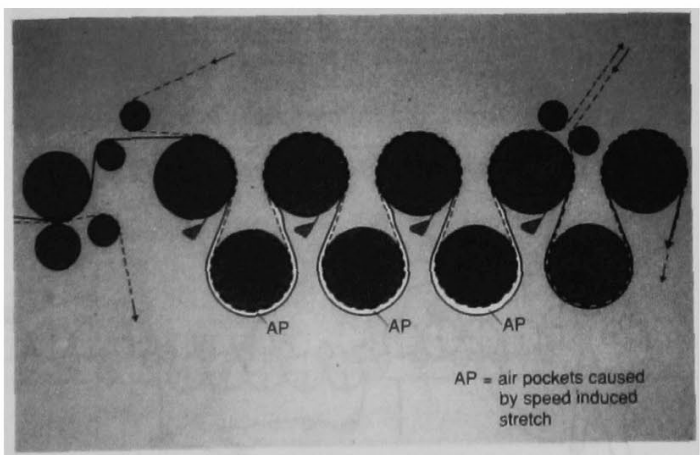

目 15 シングルフェルトにおけるェアポケットの 発生 
生じるものである。シートはそれぞれの部分で遠心力 を受け伸びてゆく。従ってシンクルドライヤにおいて 終わりの数本の回りではこのエアポケットは大きく なって断紙などの原因になる。この事を避けるために は高いドローが必要になる。

\section{4 シートタビライザーの問題点}

この問題はエッジ部に発生する。すなわち両端部か らの空気の流入と前述のゆるみにより, 空気の流れが 增加しエッジ部でのスタビライザーの効果が低下し紙 切れの原因となる。

2.5 ドライヤの凝縮によるリウェッティング

ドライヤでの安定走行を損なうもう一つの問題を図 16 に示す。本図はドライヤ内に於ける空気温度と シートの温度と露点の関係を示している。問題は 1 群 でのシートの温度か露点より低いことである。この結 果 1 群付近でシートはリウェッティンクして弱くなり, 張力の低下とマシン方向のしわを引起こす。

\section{6 現実的な対応について}

これまで述へてきた諸問題を解決するための現実的 な対応について以下に紹介する。図17はこれまでに 述へた問題に対応したレイアウトを示している。即ち, オープンドローを無くし，シートを保持するためのサ クションカンバスロールを使用したアレンジとなって いる。

図18はドライヤ全群をシンクルティアでアレンジ

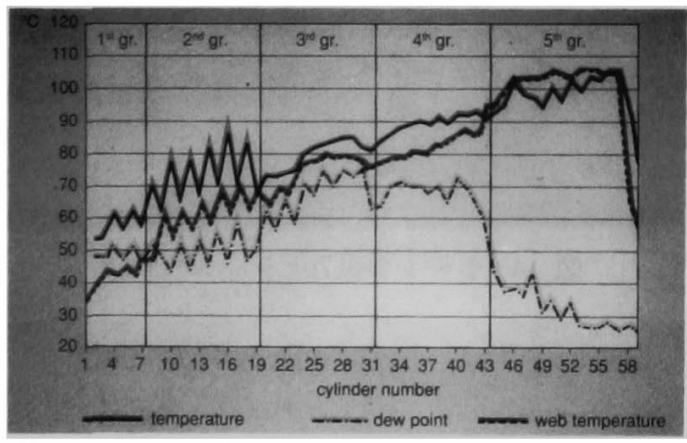

図 16 ドライヤにおけるシートの温度变化
した場合のレイアウトである。

图19はサクションキャンバスロールの配置を示し ている。この配置で重要なことは, サクションキャン パスロールとドライヤドラム間のカンバスのフリー ランの長さを最少にすることである。この目的はシー トの幅方向の収縮を最少に押えることある。さらに, $2.2 \mathrm{~m}$ 径の大径ドライヤドラムを使用することにより このフリーランの数を最少にすることも必要と考えて いる。

困20はシンクルティアドライヤの乾燥メカニズム を示す。シンクルティアドライヤの乾燥メカニズムの 特長は, シートがカンバスにおおわれている間は蒸発 は抑制されているが, いったんシートが空気にふれる とドラインクレートが 5 ～倍の值に增加し，その後こ の割合はかなり早く減少することである。

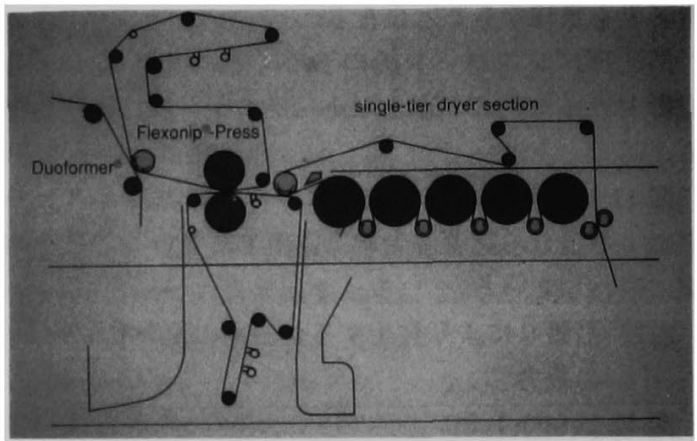

図 17 FNP からシンクルティアドライヤへの通紙

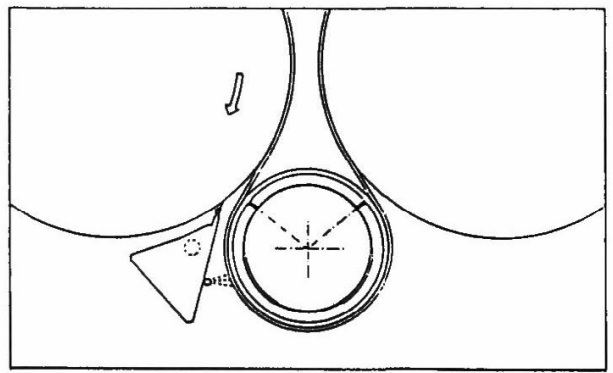

图 19 サクションカンバスロールの配置

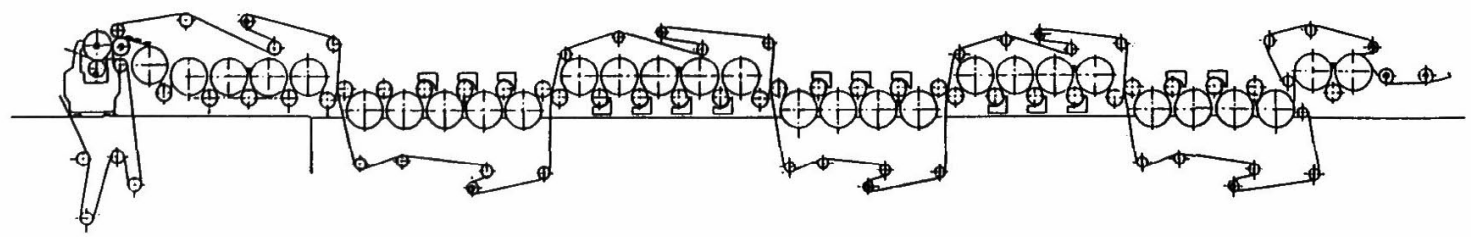

図 18 シンクルティアドライヤ 


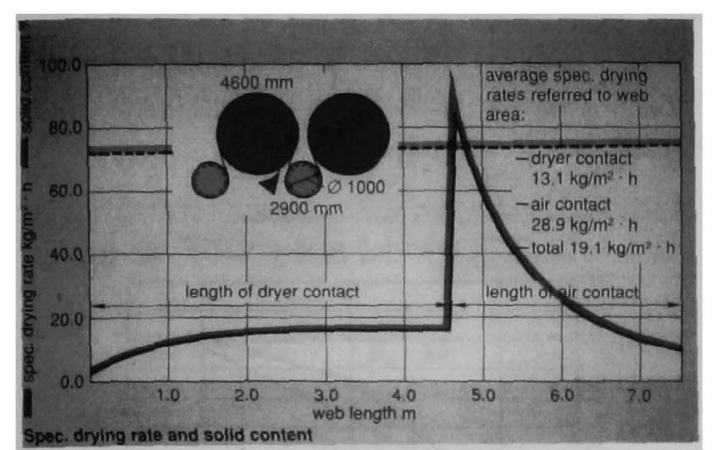

图 20 シンクルティアドライヤの乾燥メカニズム

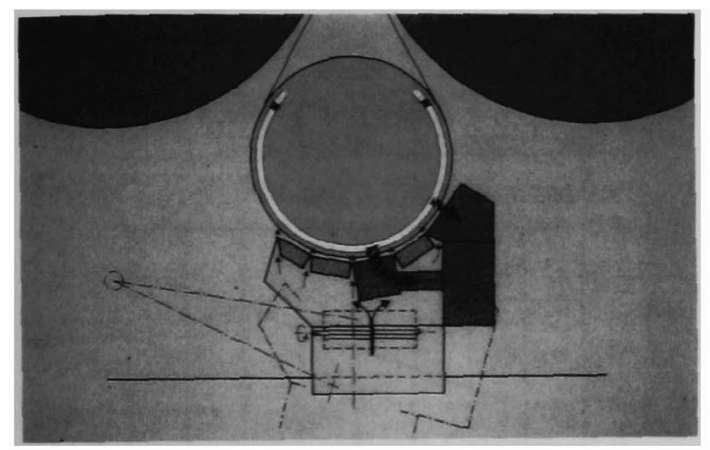

图 21 ペンチレーションボックス

図21 はシンクルティアードライヤに於いて新しく 開発されたベンチレーションボックスである。シンク ルティアードライヤのポケットは開放されており， タ フルティアドライヤのそれと比較するとそれ自身均一 なモイスチャープロファイルをもたらすが,より以上 のモイスチャープロファイルの向上, 乾燥能力を上げ ることを目的として，本装置は開発されたものである。 このボックスはシートに対してエアーを吹き出し, 同 時にシートから飽和しな空気の境界層をはきとり蒸発 を促進する。その結果, 乾嬠能力が 7 \% \%向上して いる。

\section{7 結 険}

最適な安定走行を得るためにはクーチから最終ドラ イヤまでシートをしっかりと保持することが重要であ ク,このことはシンクルティアードライヤとオープン トローのないシートトランスファにおいてのみ達成す ることかできるものと考えている。シングルティアー ドライヤは幅方向の収縮を減少させ, シートの走行性 を安定させると同時に，品質を改善させるのに役立つ ものと考えており，さらにこの効果を最大に発揮させ るためには大径ドライヤが必要となってくると思われ る。また, 新しく開発したペンチレーションホックス は乾燥能力を向上させ, 優れた水分プロフィルを作り
出すのに有効な設備である。

\section{3. フレキソニッププレス（FNP）の展望と その応用}

\section{1 理想的なニップ圧曲線}

ドライヤの高速性能と安定走行において問題になる プレス出口水分の向上とノードロープレスに対して, 大きな可能性を持っているIHI-VOITHのシュータ イププレス (Flexo Nip Press), すなわち FNPにつ いて以下に紹介する。IHI-VOITH の FNP の設計コ ンセプトは, プレスの脱水メカニズムに合った理想的 なニップ圧曲線の追及と現実的対応にある。理想的な ニップ压曲線については 1968 年国際シンポジウムで VOITH 社が発表しておりその結論を図 22 に示す。 ゆっくりと安定した圧力上昇はシートのくだけをなく して全断面を均一に濃縮する。またニップ圧の急激な 減少にリウェッティンクク防止を目的としている。これ に対し図 23 はFNPで実際に測定したニップ圧曲線 である。理想的なニップ圧曲線に極めて近い曲線であ ることが分かっていただけると思う。

\subsection{FNP の新聞用抄紙機への適用の可能性}

FNPは最初ライナー中芯のような板紙用に開発さ れた。しかしながら新聞用紙，印刷用紙についての適 用の可能性も実験により確められており，その結果を 紹介してゆきたいと思う。この実験の結果をまとめる と, 以下の事がいえる。

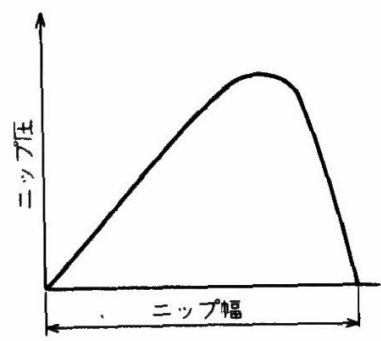

图 22 理想的なニップ圧分布

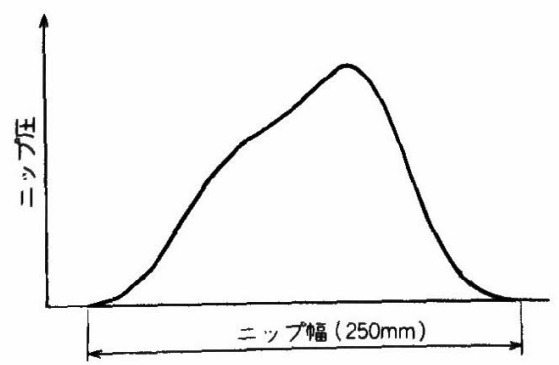

图 23 FNPのニップ圧分布 
・ロールプレスよりずっと高い乾燥度を得られる

-かさ, 不透明度, 平滑度などの紙の諸特性の低下 は見られない。

以下に報告するデータはVOITH 社実験室よりの 報告である。本実験はデュオセントリー型プレスと, 2 台の FNP と, 1 台のロールプレスプラス FNP の 3 種類の組合せでなされた。原料配合は $90 \% \mathrm{TMP}, 10 \%$ 化学パルプ, フリーネス $125 \mathrm{cc}$ で坪量 $40 \mathrm{~g}$ 及び $50 \mathrm{~g} /$ $\mathrm{m}^{2}$, 抄速 $900 \mathrm{~m} / \mathrm{min}$ の条件で実施された。

図24は3つのシステムで得られたドライネスを示 している。FNPの跹入により著しいトライネスの上 㫒がられる。

図25はFNP2段のプレスで抄速を $450 \mathrm{~m}$ から $900 \mathrm{~m}$ にあげた場合を示している。スピードが增加し ても 2 段目の後では実質的に同じドライネスとなって いる。

図26 はタブルフェルトとシンクルフェルトの比较 を示したものである。板紙の場合はタブルフェルト方 式により一般的に高いドライネスが得られるが, 柽量 紙の場合は図のようにリウェッティンクが少ないシン クルフェルトのFNPの方が好䊅果をもたらしている。

図 27 ではプレスパート出口のシートの強度を比较

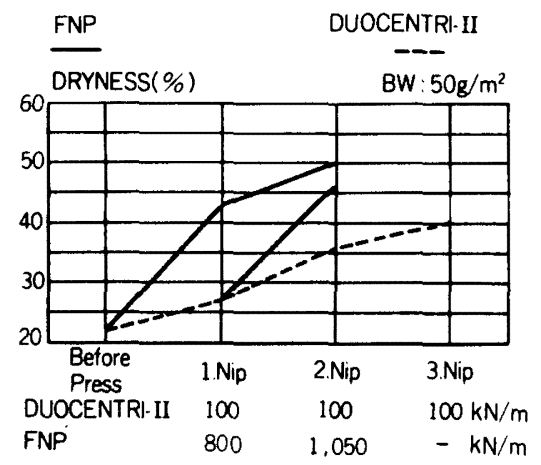

図 24 プレス出口トライネスの比較

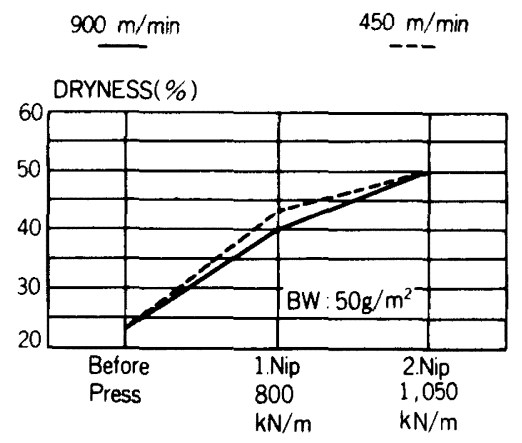

图 25 抄速とドライネス
した。強度の增加は增速に役立つものと期待される。

図 28 は乾燥度に対するかさの関係を示している。紙 のかさはプレス後の乾燥度の関数であるがFNPの方 が若千有利となっていることが分かる。
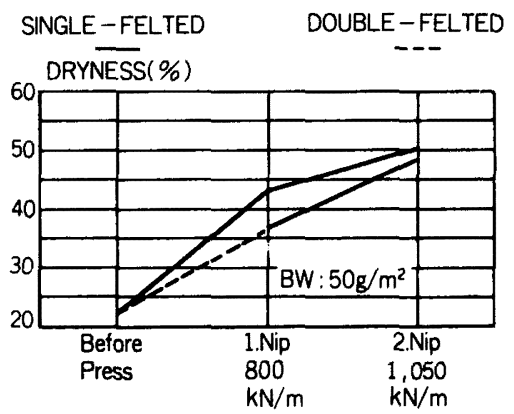

図 26 シングルフェルトとタブルフェルト

湿紙強度 $(\mathrm{Nm} / \mathrm{g})$

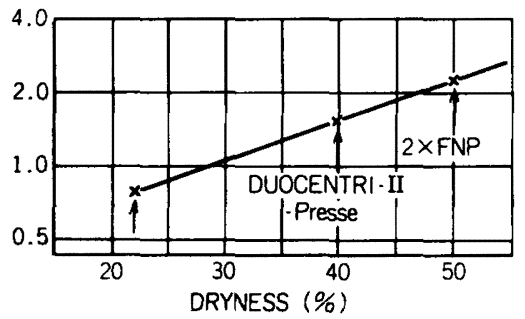

図 27 ドライネスと湿紙強度

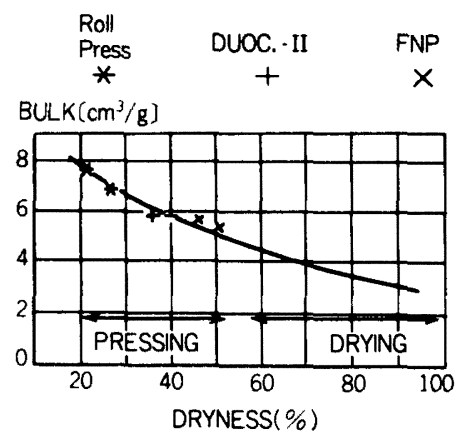

図 28 プレス形式とかさの関係

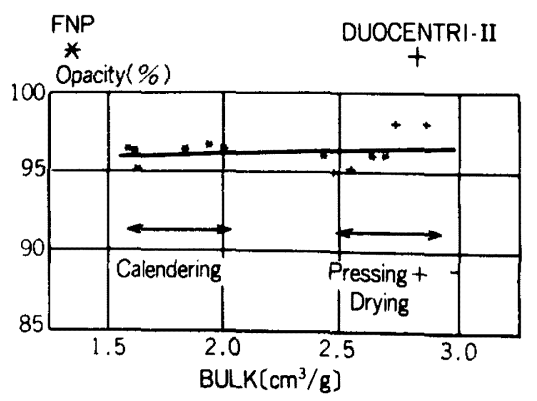

图 29 不透明度とプレス形式 


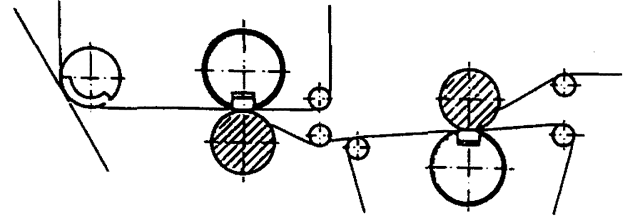

图 30 FNP を使用したプレスアレンジ-1

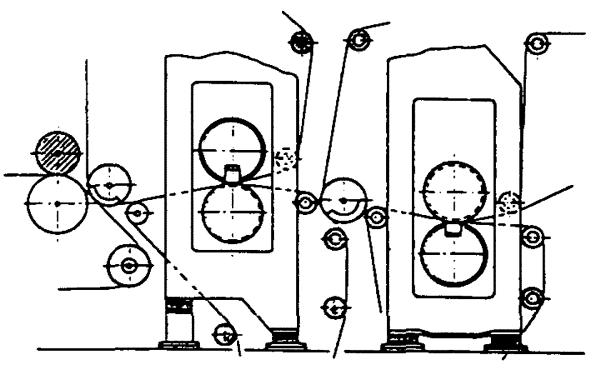

図 31 FNPを使用したプレスアレンジ-2

図 29 は不透明度とプレスシステムの関係を検討す るために整理したものであるが，不透明度とかさの同 係は予想されたようには現われなかった。またプレス システムの差も明礁には現われていない。

\subsection{FNP の徣成}

FNPの導入には各在の棈成が考えられ，跣水性，

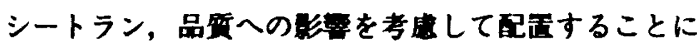
なると思われる。

図30にそれぞれシンクルフェルトを持った 2 粗の FNP からなるプレスセクションを示す。高い乾燥度か 得られる權成であるが, シートフリーランがありマシ ン運枟上はマイナスの影需を与えられることになる。 この問題を解決するための卧宣か，因31 に示すアレ

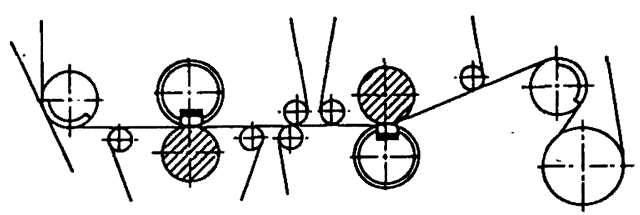

图 32 FNPを使用したプレスアレンジ-3

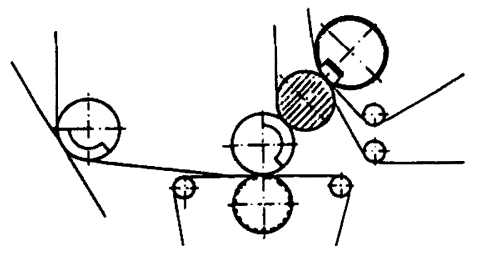

图 33 FNP を使用したプレスアレンジ-4

ンジである。この場合はリウェッティンクによりドラ イネスが多少低下することになる。

図 32 に特殊な例として 2 番プレスのボトムフェル トをシートと一緒に 1 群ドライヤにもつてゆく案を示 す。

\section{4 期 铪}

FNP (Flexo Nip Press) の迸入は柽量媇の場合に も，汦の特性に对して何らマイナスの影霎もなく乾燥 度を更に上昇させることが可能であることを本実瞼の 結果は示している。

今後の現実的な実機への適用は，デュオセントリー 型プレスに示す $3 \mathrm{P}$ または $4 \mathrm{P}$ を FNPにおきかえる 方法でスタートすることになると思われる(図 33)。い ずれにせよ，FNPを探用してゆくことは今後のプレ スパートのあり方に大きな影需を与えるものと思われ る。 